\title{
LAR AMARGO LAR: MORADIAS INSÓLITAS NAS NARRATIVAS DE CLARICE LISPECTOR E DE MURILO RUBIÃO
}

\author{
Marisa Martins Gama-KHaliL \\ Universidade Federal de Uberlândia (Brasil) \\ Conselho Nacional de Desenvolvimento \\ Científico e Tecnológico \\ mmgama@gmail.com
}

Recibido: 15-02-2013

Aceptado: 29-04-2013

(c) (i)

RESUMO

Trata-se de um estudo sobre a representação do espaço da moradia em narrativas fantásticas da literatura brasileira. Defendemos que a elaboração das referidas espacialidades é que configura, em grande escala, a ambientação fantástica na trama ficcional. Algumas narrativas fantásticas de Murilo Rubião e de Clarice Lispector, em contraponto com narrativas de Walpole, Poe, Kafka, Saramago e Cortázar, serão nosso objeto de estudo. A base teórica sobre as espacialidades será ancorada especialmente pelos estudos de Foucault, Deleuze, Guattari e Bachelard.

Palavras-Chave: literatura fantástica, espaço, moradia, Murilo Rubião, Clarice Lispector

\section{ABSTRACt}

This is a study of the representation of the dwelling space in fantastic narratives of Brazilian literature. We advocate that the elaboration of such spatialities is what configures to a large extent the fantastic setting of the fictional plot. In this paper some of Clarice Lispector's and Murilo Rubião's fantastic narratives are counterpointed to narratives by Walpole, Poe, Kafka, Saramago and Cortázar. To do so, we rely on the theoretical bases of spatialities as designed by Foucault, Deleuze, Guattari, and Bachelard.

KEYWORDS: fantastic literature, space, dwelling, Murilo Rubião, Clarice Lispector 
A narrativa mais realista que se possa imaginar desenvolve-se segundo vias irrealistas. Roland Barthes, «O efeito do real»

\section{IMPORTÂNCIA DO ESPAÇO NOS ESTUDOS LITERÁRIOS}

Se fizermos uma retrospectiva nos estudos literários, verificaremos que o espaço, como categoria narrativa, ocupou por um bom tempo na história da crítica literária uma posição inferior. Para muitos críticos, o espaço figura em uma narrativa apenas como elemento acessório, meramente decorativo. Contudo, há um grande equívoco nesse pensamento, equívoco esse denunciado por Roland Barthes quando trata do efeito do real. Barthes recorta dois episódios em que a descrição espacial é o foco — uma cena de Um coração simples, de Gustave Flaubert, e outra do historiador Michelet sobre a morte de Charlotte Corday - e argumenta que esses trechos provavelmente teriam sido desprezados em muitas análises por serem considerados "pormenores "supérfluos" (com relação à estrutura), quer por tratar esses mesmos pormenores [...] como "enchimentos" (catálises)» (Barthes, 2004: 181-182), tendo apenas um valor funcional indireto para as narrativas. Mas Barthes habilmente nos mostra o contrário, pois os espaços encenados em tais episódios engendram sentidos imprescindíveis para a compreensão das narrativas em que eles se inserem.

Assim como Barthes, Michel Foucault foi enfático ao declarar, na conferência intitulada «Linguagem e literatura», que a crítica literária por um longo tempo delegou aos estudos sobre o espaço uma posição subalterna e, por acreditar em um parentesco entre a linguagem e o tempo, os críticos dirigiram sua atenção maior às relações entre a literatura e o tempo. Foucault (2000) não desconsidera tal relação intrínseca entre linguagem e temporalidade, uma vez que a linguagem funciona no tempo, mantém-se no tempo e mantém o que expressa no tempo; contudo, se a função da linguagem é o tempo, seu ser é o espaço, porque «de modo geral, só há signos significantes, com seu significado, por leis de substituição, de combinação de elementos, por conseguinte, em um espaço» (Foucault, 2000: 168). A ordem das palavras em seu espaço discursivo interfere sobremaneira nos sentidos que elas deflagram.

Foucault (2000: 169) explica a insistência da crítica literária nos esquemas e análises temporais em função de uma tendência criacionista: «Havia a sempre necessidade, a nostalgia da crítica de encontrar os caminhos da criação, de reconstituir, em seu próprio discurso crítico, o tempo do nascimento e do acabamento que, pensava-se, deveria conter os segredos da obra». Para 
esse filósofo, a crítica deve investir em pesquisas que tenham como foco o espaço, pois as metáforas espaciais possibilitam desvelar as relações de poder envolvidas na representação literária.

Se observarmos os tradicionais estudos de narratologia, constataremos a posição subalterna delegada ao espaço ficcional, como denunciou Foucault. Para exemplificar, podemos citar o estudo «O que é uma descrição» (1976), de Philippe Hamon, inserido no livro Categorias da narrativa. Hamon, como se pode perceber pelo título do estudo, concentra sua explanação sobre a descrição; portanto, para falar do espaço ficcional, focaliza estritamente sua perspectiva de abordagem no procedimento discursivo que abriga a representação espacial. Fazemos um parêntese para observar que a descrição não está relacionada necessariamente às espacialidades ficcionais, mas pode ser, por exemplo, a projeção do estado de alma de uma personagem pelo narrador. Assim, reduzir o estudo do espaço à descrição significa alijá-lo a uma posição marginal. É evidente o ponto de vista negativo que o autor confere à descrição, considerando-a como uma pausa, um corte na narrativa; esse ponto de vista encontra-se realçado na conclusão do seu estudo: «definimos já a descrição como uma unidade que arrasta a proliferação de temas verossimilhantes [...], formando aquilo a que chamamos uma temática vazia» (Hamon, 1976: 75). O que notamos bem claramente é a assunção de uma perspectiva marginalizada de abordagem do espaço, considerado como uma categoria que interrompe o curso narrativo, avaliado como simples elemento suplementar, podendo assim ser facilmente rejeitado, uma vez que se trata de uma temática vazia. Essa posição assumida por Hamon compartilha do ponto de vista de um estudo basilar sobre a narrativa literária, o clássico «Narrar ou descrever», em que seu autor, Georg Lukács, elabora uma dicotomia que compreende a descrição desassociada dos motivos geradores da ficção, relacionando-a a um quadro estático; e a narração, inversamente, como o procedimento discursivo que articula os motivos geradores, desencadeador de episódios que constituem a dramaticidade do enredo.

Na mesma linha de entendimento da crítica marxista de Lukács, o Estruturalismo também desloca para as margens o espaço ficcional. Podemos citar um estudo de Gérard Genette, autor representativo no âmbito da narratologia estruturalista, que, no século XXI, continua sendo referência nos estudos sobre narrativa. O estudo insere-se na coletânea intitulada Análise estrutural da narrativa e nele Gérard Genette considera a descrição como mera serviçal da narração, ancillanarrationis, «escrava sempre necessária, mas sempre submissa, jamais emancipada» (Genette, 1976: 263). 
As explanações teórico-críticas que abordam o espaço ficcional a partir da dicotomia entre narração e descrição geralmente desconsideram a riqueza da espacialidade para a produção de sentidos na ficção literária e, em decorrência dessa posição, não se sustentam como fundamentação teórica para a análise de muitas obras em que o espaço não é mero componente da cena descritiva, mas um elemento repleto «de significado até o máximo grau possível» (Pound, 1970: 36). Um conto como o do brasileiro João Guimarães Rosa, «A terceira margem do rio», teria sua análise exaurida se fosse tomado como parâmetro o referencial apenas da descrição, porque a terceira margem nem ao menos é descrita pelo narrador de Rosa; contudo, é o vazio da descrição dessa margem inusitada e insólita que se constitui como um forte gerador de interpretações.

A brasileira Leyla Perrone-Moisés, em um estudo intitulado «Balzac e as flores da escrivaninha» (1990), redimensiona a função do espaço na obra literária. Tendo como base o romance O lírio do vale, de Balzac, Perrone-Moisés (1990: 46) demonstra que uma descrição nem sempre é uma temática vazia; ao contrário, no analisado romance de Balzac, as «páginas descritivas não representam uma parada da narração; elas contam coisas, as coisas que são censuradas nas páginas narrativas». Por isso as descrições balzaquianas são entendidas como metáforas —vegetais- de caráter claramente sexual. Os desejos sexuais do jovem Felix de Vandenesse pela Madame de Mortsauf são metaforizados nos buquês de flores que ele oferece a ela. Perrone-Moisés (1990: 45) esclarece que há dois tipos de metáforas: «a metáfora estática, de função redundante, qualificativa, explicativa ou enfática, e a metáfora dinâmica, com função de deslocamento, de compensação, de desrecalque. A primeira remete, circularmente, a um já-dito na narrativa; a segunda produz um outro nível narrativo». As metáforas de Balzac figuram como metáforas dinâmicas, pois remetem a um plano de sentidos interditado pela narrativa, e a descrição das flores não é feita termo a termo em correspondência com as partes do corpo da mulher e do homem, mas «por entrecruzamentos, espraiamentos, despistamentos, administrando tensões e repousos» (Perrone-Moisés, 1990: 47). Acrescentamos aqui a esse belo estudo de Perrone-Moisés: essa descrição fragmentária, composta por despistamentos, assemelha-se à forma de um rizoma, uma vez que o rizoma (Deleuze e Guattari, 1995: 32) «não é feito de unidades, mas de dimensões, ou antes de direções movediças. Ele não tem começo nem fim, mas sempre um meio pelo qual ele cresce e transborda». A possibilidade de conexão de um ponto com qualquer outro e as direções mo- 
vediças aproximam a ideia de rizoma das descrições metafóricas e espaciais de Balzac.

Metáfora, aliás, é o nome que deveriam ter os relatos, as narrativas, de acordo com Michel de Certeau. Na Grécia antiga, os transportes coletivos eram chamados de metaphorai. As pessoas se locomoviam de um espaço a outro por intermédio da metáfora. Por esse motivo, para Michel de Certeau (1994: 199), os relatos deveriam ter esse nome: «todo dia, eles atravessam e organizam lugares; eles os selecionam e os reúnem num só conjunto; deles fazem frases e itinerários. São percursos de espaços». E, sendo assim, defende que todo relato é uma prática de espaço.

Os espaços ficcionais são organizados através do processo da mimesis. A mimesis, que no ver de Barthes (2007) seria uma das grandes forças da literatura, é responsável pela construção de sua materialidade ficcional, de sua representação. Essa força participa determinantemente no processo transgressor da literatura e isso pode ser verificado pelo fato elementar de entendermos que o mundo da ficção não é, de maneira nenhuma, o mundo da realidade. A literatura tem a liberdade — poética- de construir as formas humanas, geográficas e sociais. $\mathrm{O}$ «mundo» construído pode ser desenhado mais similarmente em relação ao «real» que conhecemos, ou dele se distanciar em alguns ou muitos aspectos, como no caso da literatura fantástica. Desde os tempos mais remotos, o grande desejo da literatura é a representação do real. Porém, mesmo no caso da descrição realista, a transposição do real para o ficcional não é feita plano a plano, ponto a ponto, ela é sempre rizomática, e será rizomática por excelência no caso das espacialidades da literatura fantástica.

Mas o que vem a ser a representação? Durante séculos, nos mais variados períodos estéticos, os artistas exercitam novos e inusitados modos de projeção desse real para o mundo ficcional e discursivo da literatura, ainda que os dois mundos —o real e o ficcional— não possam coincidir topologicamente jamais, uma vez que um obedece a uma ordem unidimensional, e o outro, a uma ordem a pluridimensional. O mundo de papel, por mais que a literatura seja calcada em um realismo de representação, é ficcional, e isso não implica pensar que ele seja uma negação do real; ele atua, aliado ao imaginário, como princípio de transgressão do real e por isso sua representação é rizomática.

Temos defendido em trabalhos sobre a espacialidade literária que a relação entre o ficcional e o real pode ser entendida como uma zona de devir, um entrelugar. Para Deleuze (1997: 11), devir «não é atingir uma forma (identificação, imitação, Mimese), mas encontrar a zona de vizinhança, de indiscernibilidade ou de indiferenciação [...]. O devir está sempre entre ou no meio». 
Espaços literários são, pois, devires que se colocam ao leitor como pontos de fuga para múltiplas interpretações.

\section{A Literatura FANTÁSTICA E A ELABORAÇÃO DO ESPAÇO FICCIONAL}

A noção de devir que, no nosso ponto de vista, serve perfeitamente para caracterizar o espaço literário é a porta de entrada para a compreensão acerca dos modos de elaboração do espaço na literatura fantástica. Acontece que, no caso da literatura fantástica, podemos pensar a zona de indiscernibilidade, que caracteriza o devir, elevada a um grau máximo de indeterminação, isto é, a partir da noção de devir hiperbolizada. Da mesma forma, conforme já pontuamos anteriormente, a noção de rizoma deve ser tomada igualmente de modo pleno e hiperbólico.

Desde os castelos da literatura gótica ao castelo de Kafka, o que delineia a representação dos espaços insólitos são devires que assolam o sentido do real conhecido pelos leitores. Esses espaços erguem-se como rizomas, verdadeiros labirintos que funcionam como locais de perda.

Em seu Pós-escrito ao Nome da Rosa (1985), Umberto Eco fala-nos da existência de três tipos de labirinto: o grego, o maneirista e o pós-moderno. Quem percorre o labirinto grego, o de Teseu — que tem em seu centro o Minotauro-, encontra um fio, o de Ariadne, que o conduz à saída. O labirinto maneirista é figurativizado como uma árvore com muitas raízes, muitos becos sem saída; nele há apenas uma saída e para achá-la é preciso recorrer, ainda, ao fio de Ariadne. O labirinto pós-moderno, o rizoma, de acordo com Umberto Eco (1985: 47), «é feito de modo que cada caminho possa ligar-se com qualquer outro. Não tem centro, não tem periferia, não tem saída, porque é potencialmente infinito». O rizoma é um caule subterrâneo e a sua forma é a da multiplicidade, regida por pontos ou posições como em uma estrutura em raiz, estrutura essa formadora de tramas. Sem começo nem fim, o que importa é o intermezzo, que não deve ser visto como o centro, mas como aquilo que está num espaço intermediário, porém completamente descentrado, na medida em que o seu processo fundamental é a metamorfose dinâmica. O rizoma descrito por Deleuze e Guattari (1995) encaixa-se a configuração do rizoma/ labirinto pós-moderno estudado por Umberto Eco, e é uma concepção teórica perfeitamente adequada para caracterizar o espaço insólito. Em função disso, Deleuze e Guattari (1977: 7) abrem o livro Kafka: Por uma literatura menor com a afirmação: «Como entrar na obra de Kafka? Trata-se de um rizoma, de uma toca. O Castelo tem "entradas múltiplas", cujas leis de uso e de distribuição não 
são bem conhecidas». Notamos, então, que a entrada analítica de Deleuze e Guattari na obra de Kafka é pela via do espaço. Essa importância das construções espaciais na literatura fantástica também é realçada por Edgar Allan Poe, mestre da arte fantástica, ao explicar o modus operandi da escrita de $O$ corvo. Em A filosofia da composição, Poe admite que concedeu uma posição privilegiada ao espaço ficcional em seu poema narrativo, mostrando-nos o quanto foi importante circunscrever a cena do encontro do amante com o corvo em um espaço fechado -o quarto que abrigara o amante e sua agora ausente amada. Tal espaço, além de sugerir o efeito do insulamento, teria a força de uma moldura para aquela cena tão essencial para o enredo de $O$ corvo.

Consoante com essa visão de Poe, entendemos que o espaço ficcional é o responsável, em muitas narrativas, pela deflagração do clima insólito. $\mathrm{O}$ espaço diegético organiza-se como o cenário que possibilita o curso dos eventos narrados. A descrição dos espaços geográficos e dos espaços interiores das personagens delineia não apenas os cenários sociais, mas, especialmente, os cenários ideológicos.

Na narrativa fantástica, a inscrição do espaço é importantíssima para a exploração de regiões diferentes do real imediato. Como Todorov (2004: 37) assevera, a hesitação do leitor é a primeira condição do fantástico. No nosso entendimento, um dos principais motores para a hesitação do leitor diante do mundo por ele lido é a forma como os espaços narrativos são elaborados. Nesse sentido, acreditamos que a configuração dos espaços ficcionais, na narrativa fantástica, define em grande escala a densidade dos efeitos de sentido gerados, dentre eles o grau de estranhamento do leitor.

Nosso mirante teórico para o trabalho do espaço na literatura fantástica são algumas concepções de Michel Foucault sobre espaço, como a de utopia, heterotopia e atopia; e noções advindas dos estudos de Gilles Deleuze e Félix Guattari, como as de devir, rizoma, espaço liso e espaço estriado.

Os espaços utópicos são aqueles que delineiam o desejo de uma «sociedade aperfeiçoada» (Foucault, 2001: 415) e por isso confortam o leitor. Parece contraditório afirmar que a utopia, que é o espaço do irreal, representa a sociedade, espaço que seria, no senso comum, o da realidade. Contudo, é preciso entender que a nossa forma de ver o real — a sociedade e os seus espaços- é fundamentalmente irreal, utópica, visto que tentamos tornar linear e homogeneizar o «onde» vivemos. Os espaços heterotópicos, para Michel Foucault, concebem o real, já que eles planteiam a desordem e a fragmentação espacial e por essa razão abrem regiões que inquietam os olhares habituados a organizar as palavras, as coisas, os homens e os objetos. Por isso Foucault 
afirma que as heterotopias são «espécies de lugares que estão fora de todos os lugares, embora eles sejam efetivamente localizáveis» (Foucault, 2001: 415), são espaços que incomodam por apresentarem a multiplicidade, a justaposição e a inversão de planos, a fragmentação das perspectivas. Nesse sentido, as heterotopias se contrapõem à acomodação das utopias. Foucault observa a existência de um lugar intermediário entre o espaço utópico e o heterotópico, a atopia, que é o espaço da experiência de fronteira. Como exemplo da atopia, temos o espelho, porque ele traz a um só tempo o real e o irreal. Por meio do espelho, o sujeito é capaz de ver-se em um espaço onde não está, todavia o espelho existe realmente e tem um efeito retroativo, porquanto por meio dele a pessoa se descobre distante do lugar onde se encontra. O espaço descortinado pelo insólito desloca-se sempre do heterotópico para o atópico e geralmente contrapõe-se ao utópico. Mas obviamente encontramos algumas narrativas em que utopias descortinam o insólito, como no caso de máquinas/objetos que realizam operações cotidianamente impossíveis, como em $A$ invenção de Morel de Adolfo Bioy Casares.

Ao lidarmos com essas noções foucaultianas acerca do espaço, frequentemente as associamos com as noções de espaço liso e espaço estriado de Deleuze e Guattari (1997). O espaço liso é concebido como nômade, arquitetando-se como superfície que pode espalhar-se em multíplices direções; ele é mesclado por elementos intrínsecos entre si e ao mesmo tempo inteiramente heterogêneos. A construção do espaço liso deflagra uma propagação descentrada, que se caracteriza por transformações sucessivas e desencadeia uma trama intricada de linhas. O entrelaçado de superfícies, linhas e fluxos do espaço liso remetem ao conceito de espaço heterotópico ideado por Foucault. O espaço estriado, inversamente, é formado por meio das sedimentações históricas; ele se arquiteta de forma linear e organizada, e, nesse sentido, pode ser relacionado ao espaço da utopia sugerido por Foucault. No estriamento, existe a coordenação das linhas e dos planos, indicando a normatização da vida e a classificação de funções e lugares dos sujeitos que nele se encontram inseridos. Deleuze e Guattari lembram que nenhum espaço é de uma vez por todas liso ou estriado. Dependendo das posições ocupadas pelos sujeitos, os espaços tendem a revezar-se igualmente. 


\section{MORADIAS FANTÁSTICAS}

Dentre os espaços explorados como ambientação para as narrativas fantásticas, as moradias ocupam um lugar privilegiado em função principalmente de elas representarem para os seres humanos seu principal espaço de referência. Conforme explica Gaston Bachelard (1996: 36), «[a] casa é um corpo de imagens que dão ao homem razões ou ilusões de estabilidade». Nesse sentido, a literatura fantástica trabalha em um sentido inverso à estabilidade, porque ela privilegia o delineamento da casa associado à sensação de instabilidade e, conforme demonstraremos, de inacessibilidade.

Bachelard estuda a casa pelo fato de ela ser uma topofilia, uma vez que se desenha como abrigo do homem. Em A poética do espaço, Bachelard (1996: 19) esclarece que o seu objeto de estudo são as «imagens do espaço feliz», de «espaços louvados», espaços esses que ele conceitua como topofilia. Contrapostas aos espaços de felicidade, há construções espaciais relacionadas a experiências negativas, são os «espaços do ódio e do combate». Bachelard não conceitua os espaços negativos diretamente, mas contrapondo esses espaços àqueles que lhes são opostos (os espaços afortunados da topofilia), inferimos que os espaços da infelicidade podem ser denominados como topofóbicos. $\mathrm{O}$ estudioso brasileiro Ozíris Borges Filho (2007: 158), em uma releitura que faz da topo análise bachelardiana e de outros estudos sobre os espaços, afirma que se tem de um lado, a topofilia, associada a uma experiência benéfica, de euforia; e de outro lado a topofobia, relacionada a uma situação disfórica, maléfica.

O uso frequente da casa por boa parte da literatura fantástica deve-se muito mais a situações topofóbicas, na medida em que geralmente o que é desencadeado a partir da representação das casas insólitas é o medo, o desconforto, e não a felicidade. Conforme assinala Filipe Furtado (1980: 121), «a diegese fantástica prefere sobretudo os locais delimitados ou fechados, os ambientes interiores, particularmente a casa de grandes dimensões, as construções labirínticas». Como veremos, neste estudo, a casa insólita se dimensiona como hiperbólica em variados sentidos, suas dimensões são enormes em função de diferentes modos de trabalho com a exageração do real.

Se nos lembrarmos dos castelos góticos, logo virão à nossa mente construções espaciais que provocam o medo, como no clássico O castelo de Otranto, publicado no século XVIII, por Horace Walpole (1996: 34):

A parte subterrânea do castelo era escavada numa série de vários claustros interligados e não era fácil para alguém em tal estado de ansiedade 
encontrar a porta que abria para a caverna. Um silêncio assustador reinava nessas regiões subterrâneas, exceto quando, vez por outra, algumas rajadas de vento sacudiam as portas pelas quais ela havia passado e os gonzos de ferro ecoavam através daquele longo labirinto de trevas.

A representação do castelo de Walpole influenciará boa parte da literatura fantástica nos séculos subsequentes. No século XIX, Poe fará das moradias solo fértil para a sua literatura fantástica. Nas narrativas de Poe, os espaços redimensionados pela perspectiva dos deslocamentos e da hipérbole desencadeiam seu tom transgressor. As casas fantásticas são ideadas discursivamente por meio de uma mimesis que desconsidera a geometria e a arquitetura tradicionais. A casa de Usher figura como presença assombradora que deixa o narrador hesitante desde o princípio de sua narração (Poe, 2001: 244):

e, afinal me encontrei, ao caírem as sombras da tarde, perto do melancólico Solar de Usher. Não sei como foi, mas ao primeiro olhar sobre o edifício invadiu-me a alma um sentimento de angústia insuportável [...]. Contemplei o panorama em minha frente - a casa simples e os aspectos simples da paisagem da propriedade, as paredes soturnas, as janelas vazias, semelhando olhos [...]. Que era - parei para pensar-, que era o que tanto me perturbava à contemplação do Solar de Usher? Era um mistério inteiramente insolúvel.

A casa parece ser à primeira vista apenas uma morada qualquer, como o próprio narrador reconhece («casa simples», «aspectos simples»). Todavia, paradoxalmente ela desperta no narrador um mistério insolúvel e uma angústia insuportável. Na medida em que vai adentrando o Solar, a angústia do narrador cresce, pois ele depara com arquiteturas, objetos e formas espaciais que lhe são aterradores, tais como «corredores escuros e intrincados», "sombrias tapeçarias», «fantasmagóricos troféus» (Poe, 2001: 246). A feição labiríntica e plenamente rizomática é evidente nas descrições do castelo, descrições que nada têm de estáticas, pois esse espaço será muito mais que apenas o lugar dos acontecimentos terríveis da trama.

Nessa narrativa de Poe, temos a história de um irmão, sua irmã gêmea e sua casa — todos imbricados, como se fossem um só ser. E é o espaço que desempenha o vértice desse triângulo; ele assume a função de protagonista da trama. O solar de Usher é a alma dos Usher. O narrador, que visita os dois irmãos, percebe que aquela construção não é um simples espaço físico. A mera contemplação do solar, quando da sua chegada, o perturba, é um mistério para o qual tenta abrir plausíveis explicações, contudo acaba admitindo que 
as deduções lógicas não permitem elucidar tudo: «se há, sem dúvida, combinações de objetos muito naturais que têm o poder de assim influenciar-nos, a análise desse poder, contudo permanece entre as considerações além de nossa argúcia» (Poe, 2001: 244). Ao longo de toda a narração acontece uma predominância de trechos referentes à descrição do solar, justamente porque o narrador entende que esse espaço é o culpado pela demência de seu amigo: «efeito que o físico das paredes e torreões cinzentos e do sombrio pântano em que esse conjunto se espelhava, afinal, produzira sobre o moral de sua existência» (Poe, 2001: 248). E tal espaço é responsável ainda pelo terror crescente e contínuo que ele sentiu na época em que lá se hospedou. Vimos que, a princípio, o solar parece ser uma «casa simples», entretanto, com o passar do tempo, ele se torna cada vez mais monstruoso: «Tentei levar-me a crer que muito, senão tudo aquilo que sentia, se devia à impressionante influência da sombria decoração do aposento, dos panejamentos negros e em farrapos» (Poe, 2001: 253). A tentativa de que fala o narrador é a de estriar o que se alisa, organizando o insólito em suas deduções. Quando foge de uma cena em que a suposta irmã levanta-se da morte (ou catalepsia?) e ataca mortalmente o seu irmão, o narrador deixa para trás o solar. É dele que precisa fugir e é a descrição dele que oferece ao leitor, nas últimas linhas do conto, a descrição do desmoronamento da edificação.

Quando se trata de moradias insólitas, é impossível não trazer à cena $O$ castelo, de Franz Kafka. Escrita no início do século XX, essa narrativa kafkiana é um exemplo do espaço rizomático, conforme já pontuamos anteriormente com base na análise de Deleuze e Guattari (1977). Nela, K. é contratado como agrimensor por um conde, e no dia seguinte à sua chegada à aldeia resolve ir ao castelo anunciar a sua presença, entretanto percebe que essa é uma tarefa impossível. Há uma recusa ao seu trabalho; mais ainda: a recusa maior é ao seu acesso ao castelo. O castelo labiríntico e inacessível faz com que K., em suas idas e vindas ao redor do castelo, desconfie da sua própria existência. Algumas de suas portas se abrem, mas interditam o caminho que está por vir (Kafka, 2000: 275):

O corredor propriamente dito estava, na verdade, deserto, mas as portas já se achavam em movimento, continuamente uma delas se abria um pouco e se fechava depressa; esse abrir e fechar de portas zunia na passagem, aqui e ali K. enxergava lá em cima, no espaço livre das paredes que não chegavam ao teto, cabeças de cabelos matinalmente revoltos que apareciam e logo desapareciam. 
Kafka resgata o desenho labiríntico das moradias fantásticas de escritores que o antecederam e redimensiona a maneira de plantear esse espaço, realçando a sua inacessibilidade. Essa tendência de trabalho com o espaço será resgatada por muitos autores, como por José Saramago (1998), em O conto da Ilha Desconhecida, e Julio Cortázar (2005), em «A casa tomada». No caso da narrativa de Saramago, muitas portas existem no castelo, mas o homem que queria um barco não consegue entrar em nenhuma delas. $\mathrm{O}$ máximo que consegue é impedir o trânsito em uma delas. A inacessibilidade a esse espaço colocará em dúvida o seu acesso ao espaço do seu desejo: a ilha desconhecida. Em «A casa tomada», o narrador e sua irmã Irene vão perdendo gradativamente espaço em sua própria casa; acuados, perdem o acesso a aposentos imprescindíveis:

Lembrarei sempre com toda a clareza porque foi muito simples e sem circunstâncias inúteis. Irene estava tricotando no seu quarto, por volta das oito da noite, e de repente tive a ideia de colocar no fogo a chaleira para o chimarrão. Andei pelo corredor até ficar de frente à porta de mogno entreaberta, e fazia a curva que levava para a cozinha quando ouvi alguma coisa na sala de jantar ou na biblioteca. O som chegava impreciso e surdo, como uma cadeira caindo no tapete ou um abafado sussurro de conversa. Também o ouvi, ao mesmo tempo ou um segundo depois, no fundo do corredor que levava daqueles quartos até a porta. Joguei-me contra a parede antes que fosse tarde demais, fechei-a de um golpe, apoiando meu corpo; felizmente a chave estava colocada do nosso lado e também passei o grande fecho para mais segurança. [...]

-Tive que fechar a porta do corredor. Tomaram a parte dos fundos (Cortázar, 2005: 9).

O evento foi simples, ainda que o narrador não consiga explicá-lo racionalmente. Ele e a irmã Irene, moradores daquele antigo casarão em Buenos Aires, de uma hora para outra, vão ficando encurralados. A casa vai fechando-os cada vez mais e conduzindo-os a um insulamento em determinados aposentos, até que são obrigados a deixar a casa e jogar sua chave no ralo da calçada. Mais uma vez, o que se pode notar é o tema da inacessibilidade. O lar, local de abrigo, o universo do homem, como afirma Bachelard (1996), nesse caso torna-se estranho, sobrepujando seus habitantes, segregando-lhes em um não-espaço de intimidade, a rua. 


\section{Lares amargos lares de Clarice Lispector e Murilo Rubião}

Elegemos como objetos de estudo centrais de nossa explanação sobre moradias insólitas o conto «A mensagem», de Clarice Lispector, e os seguintes contos do escritor mineiro Murilo Rubião: «O edifício» e «O bloqueio». Tomamos autores de produção frutuosa na literatura brasileira, entretanto ressaltamos que os dois possuem trajetórias diferentes, uma vez que Clarice Lispector não é conhecida como autora de narrativas fantásticas —ainda que tenha contos onde o insólito é tema central ou indireto-, e Murilo Rubião, que é considerado pelos críticos como uma das maiores expressões da literatura fantástica brasileira no século XX. Antonio Candido assinala em «A nova narrativa» a importância de Murilo Rubião no cenário da literatura no Brasil, pois esse autor mineiro conseguiu elaborar contos insólitos em um momento estético «de predomínio do realismo social, propondo um caminho que poucos identificaram e só mais tarde outros seguiram» (Candido, 2006: 252).

Um dos maiores autores da literatura fantástica da América Latina, Julio Cortázar, foi leitor assíduo das obras de Clarice Lispector e de Murilo Rubião. O tradutor de várias obras de Cortázar no Brasil, Remy Gorga Filho, relata: «Ele gostava de conversar e falava muito sobre a Clarice Lispector [...]. Ele dizia que o mineiro Murilo Rubião foi o primeiro autor do fantástico latino-americano, antes mesmo dele, Cortázar» (Gorga Filho apud Silveira, 2012).

Comecemos nossa análise pela narrativa de Clarice Lispector, «A mensagem» (1987), já que há, inclusive, uma controvérsia de que ela poderia ser considerada como uma falsa narrativa fantástica.

A casa enigmática de Clarice Lispector aparece aos olhos das duas personagens como um espaço que une paradoxalmente angústia e calma. As duas personagens são um jovem e uma jovem que se unem porque ambos sentem «angústia». Aliás, esse sentimento é que rompe o preconceito do rapaz e facilita o seu encontro com a moça: «ele se viu falando com ela na sua própria angústia, e logo com uma moça! ele que de coração de mulher só recebera o beijo da mãe» (Lispector, 1987: 125). A angústia tornou-os híbridos e fez com que passassem a ser companheiros.

Como insiste o narrador em duas passagens: «o tempo ia passando» (Lispector, 1987: 131) e nada se modificava, tudo permanecia estático. O acontecimento que propiciou uma mudança radical na trajetória dos dois não foi temporal, mas espacial: o encontro dos dois jovens com a casa, que se situava em um ambiente urbano, perto do Cemitério São João Batista. Eles ficam insulados entre o movimento dos ônibus na rua e a imobilidade da casa, com- 
pletamente encostada junto à calçada: «Naquele mínimo instante em que se buscaram inquietos, viraram-se ao mesmo tempo de costas para os ônibus —e ficaram de pé diante da casa» (Lispector, 1987: 133). Entre o avassalador movimento dos ônibus e o monumento gigantesco e estático da casa, os dois sentem-se encurralados. Mas é a casa que se imporá a eles, abissal e arrebatadora.

A casa estava ali, plantada diante deles, era uma «grande casa enraizada» (Lispector, 1987: 134). Para Bachelard (1996: 41), a casa com raiz «converteu-se em um ser da natureza», ela desencadeia nos seres «um medo cósmico, um medo antropocósmico que faz eco à grande lenda do homem entregue às situações primitivas».

Era uma casa «angustiada» e «pesava no peito dos dois meninos»; «forte como um boxeur sem pescoço» (Lispector, 1987: 134), surge provocando-os, figurando-se enorme e monstruosa, uma «casa sem olhos, com a potência de um cego». Essa casa, personificada, como a casa de Poe, cresce aos olhos de quem a olha, invade-lhe a intimidade, torna-se insólita e «para habitá-la é preciso maior elasticidade de devaneio, um devaneio menos desenhado» (Bachelard, 1996: 66). O devaneio deve articular-se «menos desenhado» porque ele é liso, heterotópico e rizomático, tal como a casa. Sobre o estado de cegueira da casa, o narrador adverte que não sabe ao certo se é em função de ela não ter olhos ou os tem, mas são vazios, como o das estátuas. Ou seja, a casa não permite o acesso dos olhos dos dois jovens; eles até podem olhá-la, porém não conseguem mirar nos olhos dela, seja porque ela não os tem, seja porque são ocos. E esse fato comprova a inacessibilidade da casa de «A mensagem», como a de Kafka, por exemplo.

E, além de ser aterradora, enorme, a casa fala com os dois jovens: «Eu sou enfim a própria coisa que vocês procuravam, disse a casa grande. E o mais engraçado é que não tenho segredo nenhum, disse também a grande casa», deixando-os «presos pelo fascínio e horror» (Lispector, 1987: 135). A partir desse momento de horror, os dois, que nunca haviam pensado no futuro passam a projetar se o viveriam. Ocorre, então, uma mudança brusca com os dois jovens no encontro súbito com aquela casa horrífica. Amadurecem. Ele torna-se homem e passa a fumar um cigarro imaginário e ela percebe-se pintada com batom e ruge; eles adquirem a sua primeira solidez e finalmente se separam.

Há pouquíssimos estudos sobre o insólito nas narrativas de Clarice Lispector, e um dos mais conhecidos, de Leyla Perrone-Moisés, intitulado «A verdade fantástica de Clarice» (1990) acaba por negar o fantástico da narra- 
tiva, instigando-nos a lê-lo como um falso fantástico. Para fazer sua análise, a autora realiza um estudo comparado, tendo como foco «A mensagem», de Clarice Lispector, "A estranha casa da alta bruma», de Lovecraft, e "A queda do Solar de Usher», de Poe. Vejamos um trecho do estudo citado (Perrone-Moisés, 1990: 168):

O conto de Clarice é mais perverso do que qualquer conto fantástico. A perversidade do fantástico consiste em colocar as personagens (e o leitor) num estado de mal-estar decorrente da ignorância de uma explicação lógica. Entretanto, no fim dos contos fantásticos, o pesadelo termina: quer a personagem morra, quer escape, a história acaba. O leitor, por sua vez, fecha o livro e volta a suas ocupações habituais, aliviado por não ter vivido ele mesmo aquela aventura. Era apenas uma «história extraordinária», cuja inquietante estranheza foi superada.

O conto de Clarice, porém, não libera o leitor no seu final. Sua história é extraordinária, mas aterradoramente comum.

Não concordamos com esse entendimento, uma vez que não se sustenta a ideia de que o conto de Clarice Lispector não libera o leitor no final e que o conto fantástico, como o de Poe, por exemplo, libera-o. Observando-se dessa forma, parece que o conto de Poe e outros contos fantásticos não se constituem como obra aberta, e não é absolutamente isso que acontece exatamente em «A queda do Solar de Usher»; pelo contrário, pois algumas explicações racionais que o narrador expõe para os acontecimentos fantásticos na mansão dos Usher são expostas como sugestões e não como afirmações. A casa desaba no final quer pelas rachaduras anteriores ou por ser consequência do desmoronamento humano? A casa era a alma dos Usher e, se eles desabam, ela tende a desmoronar também?

Parece-nos que Perrone-Moisés considera o fantástico pela perspectiva todoroviana, como se pode notar pelas referências no seu estudo e isso explica sua atitude de conceber o fantástico de Clarice como um falso fantástico, porque na perspectiva de Todorov (2004) o fantástico é um gênero que tem determinadas características e se encerra em determinado período histórico-estético. Para Todorov, a obra de Kafka desvincula-se do fantástico clássico por ele estudado em Introdução à literatura fantástica (1970), porque, dentre outros motivos que o teórico búlgaro elenca, na narrativa kafkiana, o acontecimento sobrenatural não produz nenhuma vacilação. Por não concordarmos nesse aspecto com Todorov, pois adotamos a visão do fantástico como um modo e não como um gênero, discordamos também dos argumentos utilizados por Perrone-Moisés. 
Somos acordes com a posição assumida por Flavio García, porque também compreendemos que a manifestação do insólito em uma narrativa insere-a no campo da literatura fantástica, ou, do modo fantástico (García, 2011: 4):

Em oposição, entre a teoria deles [de Todorov e de Bessière], verificamse, principalmente, a engessada estrutura genológica proposta por Todorov - em que, se muda um traço na construção narrativa, muda o gênero em que se realiza- e a abrangente construção discursiva modal sugerida por Bessière - na qual a simples manifestação do insólito e a incerteza diante de sua irrupção garantem a realização do fantástico.

Enigmáticas, casas como a de Clarice Lispector em «A mensagem», pelo simples existir, assolam de medo os homens. São casas que, a princípio ao menos, nada têm de explicitamente aterrador, de horrível, a não ser o aspecto, suas arquiteturas austeras e antigas. O horror provocado surge do jogo bem elaborado e deslocador entre a mimesis e a semioses, pois são as palavras que emanam do texto para a caracterização das casas que tornam a sua representação assustadora. É pela ausência e pela irrealização que a transgressão acontece. $\mathrm{O}$ nada assombrado converte-se, na sua relação com as personagens, em demasiado assombroso. As percepções dos protagonistas fazem emergir o assustador. $\mathrm{O}$ que notamos são deslocamentos em relação ao gênero: a tradicional construção da casa mal assombrada é reverberada em construção assombrada pelos olhos de quem observa. Irrealização do já-dito como fonte de transformação e transgressão do próprio discurso fantástico.

Se em Clarice Lispector já vimos a presença de espaços urbanos como componente do fantástico, em dois contos de Rubião a ambientação da urbe se impõe por meio de edifícios. Gaston Bachelard (1996: 45) assim explica a relação entre edifícios e cotidiano humano: «À falta de valores íntimos de verticalidade, é preciso acrescentar a falta de cosmicidade da casa das grandes cidades. As casas, ali, já não estão na natureza. As relações da moradia com o espaço tornam-se artificiais. Tudo é máquina e a vida íntima foge por todos os lados».

«O edifício» narra a história de uma construção ao infinito; uma edificação ilimitada: «Mais de cem anos foram necessários para se terminar as fundações do edifício que, segundo o manifesto de incorporação, teria ilimitado número de andares» (Rubião, 1999: 159). Em «O edifício», podemos ler sua relação dialógica e intertextual com o episódio bíblico da Torre de Babel no livro de Gênesis, na medida em que o conto de Rubião resgata a ideia forte que se tem no texto bíblico, ou seja, o hiperbólico e infindo tamanho da construção, 
bem como a ideia de poder incomensurável dos envolvidos na grandiosa e imponente construção. "O bloqueio» é um conto que segue o inverso do enredamento de «O edifício», pois a trama é sobre um edifício que desaparece aos poucos, que se desfaz paulatina e sub-repticiamente diante dos olhos do protagonista, para o seu desespero absoluto.

Em «O edifício», num momento posterior ao remate dos alicerces (a fundação dos alicerces durara cem anos), o Conselho Superior da Fundação designa o engenheiro João Gaspar como responsável pela construção de uma edificação com interminável número de andares. Nada lhe informam acerca das finalidades daquele enorme edifício, porém ele não se importa por essa ausência de justificativas, pois o que o motivava era o orgulho de dirigir a construção do maior arranha-céu de que se teve notícia até aquele momento. As ordens que the foram delegadas pelo Conselho se referiam à supervisão de um clima harmônico na construção e, para tanto, caberia a ele proporcionar aos trabalhadores salários extraordinários e assistência total. O excessivo zelo em relação à harmonia no ambiente de trabalho era consequência da «lenda» de que ocorreria uma «irremovível confusão no meio dos obreiros ao se atingir o octingentésimo andar do edifício» (Rubião, 1999: 160).

O conselho advertiu-o de que não deveria alimentar esperanças de findar a obra. O engenheiro João Gaspar desempenhou de forma exemplar as suas incumbências. Finalmente, na ocasião da festa em homenagem ao término do octingentésimo andar do edifício, «o álcool ingerido em demasia e um incidente de pequena importância provocaram um conflito de incrível violência» (Rubião, 1999: 162). Depois desse acontecimento, o engenheiro enclausura-se em sua casa, crendo que o cumprimento da lenda provocaria o fenecimento do edifício. Os operários procuram João Gaspar e comunicam a ele que as obras transcursavam na mais tranquila ordem. O engenheiro fica feliz e resolve escrever uma carta ao Conselho, mas qual não é a sua surpresa quando descobre que o Conselho se dissolvera após a morte de todos os seus membros. João Gaspar, atônito e insano por não ter mais ordens a cumprir e por desconhecer totalmente o motivo daquela construção, passa a proferir infindáveis discursos contra a obra, tentando demover os operários de tal empreitada, mas estes não dão ouvidos e o edifício continua a crescer ilimitadamente.

Em «O bloqueio», o ilimitado ocorre de maneira inversa, porque o prédio em que Gérion reside, depois de ter se separado de sua esposa Magarerbe, começa a sumir de maneira indefinida e contínua; primeiramente os andares superiores se desfazem, reduzindo-se «a fino pó amontoado nos cantos» (Ru- 
bião, 1999: 246); em seguida, no momento em que decide abandonar o prédio, os andares inferiores também principiam o procedimento de desaparecimento, até que Gérion fecha a porta com a chave e o conto termina com um vazio textual que leva o leitor a indagar-se sobre o destino de Gérion: sumirá com o edifício?

O edifício em que Gérion vai residir é o espaço da imaginação, da aparente utopia, apetecido por ele para materializar a fuga do seu antigo lar; todavia, à medida que ele se aloja no plano plausível da utopia, esse plano se dissipa, restando-lhe um espaço densamente heterotópico, fragmentado. Entretanto, por querer resistir naquele espaço utópico, ali se encerra valendo-se do último recurso: fechando a porta. Por debaixo desta, continuavam a penetrar luzes coloridas, luzes do desaparecimento.

As duas narrativas rubianas apresentam enredos que se compõem fundamentalmente através de recursos da literatura fantástica. Um edifício ilimitado em seu crescimento, num processo que leva ao infinito; um outro edifício que, opostamente, delineia uma trajetória que induz ao vazio. Circunstâncias insólitas que deflagram certamente no leitor o estranhamento. Nos dois contos, o insólito promove-se centralmente pelo trabalho com a categoria do espaço ficcional. Os edifícios, moradias ordinárias dos sujeitos que moram nas cidades, passam a ser, nas narrativas em questão, locais de propulsão do extraordinário.

Os planejamentos espaciais das cidades foram pensados, ao longo da História, para o melhor aproveitamento das extensões habitadas. Durante a Idade Média, a repartição social dos lugares era deliberada pelas oposições das classes hierárquicas; por exemplo, os lugares sagrados se contrapunham aos espaços profanos; os abertos, aos fechados. Foucault define esse período como constituído pelo espaço da localização. Depois de Galileu, projetam-se novos modos de distribuições espaciais e inicia-se o espaço da extensão, porque «o verdadeiro escândalo a obra de Galileu não foi tanto ter descoberto, ou melhor, ter redescoberto que a Terra girava em torno do Sol, mas ter constituído um espaço infinito, e infinitamente aberto» (Foucault, 2001: 412). Após o século XX, os homens vivem o espaço do posicionamento, visto que o homem não pode mais situar-se aleatoriamente em qualquer espaço; ele tem de saber onde pode posicionar-se, em que espaço não estará ocupando o local do outro: «é também o problema de saber que relações de vizinhança, que tipo [...] de circulação, de localização, de classificação dos elementos humanos devem ser mantidos de preferência em tal ou tal situação para chegar a tal ou tal fim. Estamos em uma época em que o espaço se oferece a nós sob a forma de rela- 
ções de posicionamentos» (Foucault, 2001: 413). A época do posicionamento é marcada pelas heterotopias, dos espaços que incomodam apesar de serem projetados para acomodarem, confortarem. Em função dessa era do posicionamento, Foucault acredita que as inquietações dos homens decorrem muito mais de questões espaciais do que temporais.

As moradias nos centros urbanos se verticalizaram para acomodar mais indivíduos em menores extensões horizontais. Nas cidades, há uma concorrência relacionada à construção de edificações cada vez mais altas, uma competição que parece ter como meta o alcance do mais infinito celeste. E é essa ironia que aparece sugerida pelo conto «O edifício». O leitor tem notícias de prédios cada vez mais altos, não obstante seu estarrecimento sobrevém do fato de ver no conto uma edificação que ultrapassa oitocentos andares, a despeito da lenda que pairava sobre ela.

O programa espacial das urbes adota o modelo do espaço estriado, porém nos dois contos analisados ocorre o alisamento desses espaços. Assim, podemos perceber que as duas narrativas sugerem críticas acerca do estriamento dos espaços sociais, bem como à submissão cega dos homens a tais estriamentos. $\mathrm{O}$ fato de, em «O edifício», o engenheiro João Gaspar assumir seu posto sem ao menos saber a finalidade de uma construção tão ilimitada, bem como dos operários em continuar a obra, mesmo depois de João Gaspar ordenar a sua paralisação, funciona como metáfora de uma submissão ao estriamento planteado pela sociedade. O servilismo destemperado não deixa as personagens perceberem que o estriado não é mais estriado, ele se alisa cada vez mais que atinge dimensões fora da escala da normalidade das construções comuns às grandes urbes. Um edifício de uma extensão tão ilimitada entra no plano das estruturas lisas, pois a sua propagação é desmesurada. Na narrativa «O bloqueio», igualmente ocorre a projeção de um espaço liso numa estrutura que comumente é estriada. Quando o edifício some, ele se alisa. Tanto em «O edifício» como em «O bloqueio», é o delineamento do espaço liso que confere às histórias a deflagração do fantástico, ou ainda, é o convívio com o espaço liso como se ele fosse estriado que acresce tal deflagração. Por serem lisos, os dois edifícios, a exemplo da casa de Lispector, também se tornam inacessíveis aos seus habitantes - um por tanto crescer e outro por tanto sumir, dimensões rizomáticas hiperbólicas do devir ficcional.

Os espaços habitáveis promovem lendas sobre moradias fantásticas. O que é utopia deixa de ser ou o que é real torna-se utópico? Como já vimos, para Foucault, há três tipos de posicionamentos espaciais que podem ser tomados como princípios de entendimento da relação do homem com o mundo: 
o espaço utópico, o espaço heterotópico e o espaço atópico. Esses espaços se separam, mas em muitas circunstâncias aparecem entrelaçados, mudando de função, de lugar. Os dois contos, em virtude do trabalho intenso com o insólito, desvelam um procedimento que se caracteriza pela alquimia dos espaços descritos por Foucault. O edifício ilimitado é utópico, lendário e, ao mesmo tempo, desvela-se heterotópico, plural, multíplice. Ele é lenda e a um só tempo é real, concreto; suas bases ali estão, mas o cimo aonde chegará? O edifício que some é, como afirmamos anteriormente, tomado por Gérion, como espaço de fuga, utópico, até o momento em que ele descobre que o vazio toma conta do prédio. Atopia? Caos? Afasia.

Como no Solar de Poe, no Castelo de Kafka, na Casa tomada de Cortázar e na casa espantosa de Clarice Lispector, os edifícios de Rubião se caracterizam como espaços que sobrepujam sua inacessibilidade em relação às personagens. Em todos os casos esses espaços transgridem as normas do habitável e funcionam não como espaço do acolhimento, mas como espaço de repulsa.

Neste estudo focalizamos as moradias como espaços responsáveis em grande escala pela deflagração da atmosfera insólita nas narrativas e, pelos nossos argumentos, procuramos demonstrar que tais espaços modificam o delineamento da mimesis tradicional, permitindo o contato do leitor com uma mimesis que se elabora como um rizoma, já que qualquer ponto pode conectar-se a outro ponto do desenho espacial. A paisagem fantástica sugere-se como a escrita proposta por Deleuze e Guattari (1995: 13): «Escrever nada tem a ver com significar, mas com agrimensar, cartografar, mesmo que sejam regiões ainda por vir». O que implica pensar que o escrito, a narrativa, não deve estar vinculada à dicotomia significante/significado de forma simplificada, pois a relação não é direta e linear, mas porosa, porque há zonas entre os significantes e significados que esboçam devires que se esparramam a cada escrita e a cada leitura que se faz dessa escrita, regiões rizomáticas, plenamente movediças.

BiBLIOGRAFIA

Bachelard, Gaston (1996): A poética do espaço, Martins Fontes, São Paulo. (2007): Aula (trad. Leyla Perrone-Moisés), Cultrix, SãoPaulo.

BARTHES, Roland (2004): «O efeito do real», in O rumor da lingua, Martins Fontes, São Paulo, pp. 181-198. 
Borges FILHo, Ozíris (2007): Espaço e literatura: introdução à topoanálise, Ribeirão Gráfica e Editora, Franca.

CANDIDO, Antonio (2006): «A nova narrativa», in A educação pela noite, Ouro sobre Azul, Rio de Janeiro, pp. 241-260.

Certeau, Michel de (1994): A invenção do cotidiano 1: As artes do fazer (trad. Ephraim Ferreira Alves), Vozes, Petrópolis.

Cortázar, Julio (2005): «A casa tomada», in Alicia Ramal (org. e trad.), Contos latino-americanos eternos, Bom Texto Editora, Rio de Janeiro, pp. 7-9.

Deleuze, Gilles (1997): «A literatura e a vida», in Crítica e clínica (trad. Peter PalPelbart), Ed. 34, São Paulo, pp. 11-16.

Deleuze, Gilles, e Félix Guattari (1977): Kafka: Por uma literatura menor (trad. Julio Castañon Guimarães), Imago, Rio de Janeiro.

(1997): Mil Platôs: capitalismo e esquizofrenia, vol. 5 (trad. Peter PálPelbart e Janice Caiafa), Ed. 34, Rio de Janeiro.

(1995): Mil Platôs: capitalismo e esquizofrenia, vol.1 (trad. Aurélio Guerra Neto e Célia P. Costa), Ed. 34, Rio de Janeiro.

Eco, Umberto (1985): Pós-escrito a O nome da Rosa (trad. Letizia Zini Antunes e Álvaro Lorencini), Nova Fronteira, Rio de Janeiro.

Foucault, Michel (2000): «Linguagem e literatura», in Roberto Machado, Foucault: a filosofia e a literatura, Jorge Zahar, Rio de Janeiro, pp. 137-174.

(2001): «Prefácio à transgressão», in Manoel Barros da Motta (org.). Estética: literatura e pintura, música e cinema (trad. Inês Autran Dourado Barbosa), Forense Universitária (Ditos e Escritos III), Rio de Janeiro.

FURTADO, Filipe (1980): A construção do fantástico na narrativa, Livros Horizonte, LIsboa. GARCíA, Flavio (2011): «Fantástico: a manifestação do insólito ficcional entre modo discursivo e gênero literário - literaturas comparadas de língua portuguesa em diálogo com as tradições teórica, crítica e ficcional», in Anais do XII Congresso Internacional da ABRALIC: Centro, Centros - Ética, Estética. disponível em <http: / / www.abralic.org.br/anais / cong2011 / AnaisOnline/ resumos / TC0010-1.pdf> [15 novembro de 2012].

Genette, Gérard (1976): «Fronteiras da narrativa», in Roland Barthes et al., Análise estrutural da narrativa, Vozes, Petrópolis, pp. 255-274.

HAMON, Philippe (1976): «O que é uma descrição?», in Françoise Van Rossun-Guyon, Philippe Hamon e Daniele Sallenave, Categorias da narrativa, Vega, Lisboa, pp. 57-76.

KafKA, Franz (2000): O castelo (trad. Modesto Carone), Companhia das Letras, São Paulo.

LisPeCtor, Clarice (1987): «A mensagem», in Felicidade clandestina, Nova Fronteira, Rio de Janeiro.

Perrone-Moisés, Leyla (1990): «A fantástica verdade de Clarice», in Flores da escrivaninha, Companhia das Letras, São Paulo, pp. 159-177.

(1990): «Balzac e as flores da escrivaninha», in Flores da escrivaninha, Companhia das Letras, São Paulo, pp. 44-66.

POE, Edgar Allan (2001): Ficção completa, poesia E ensaios, Nova Aguilar, Rio de Janeiro. 
Pound, Ezra (1970): Abc da literatura, Cultrix, São Paulo.

RuBião, Murilo (1999): Contos reunidos, Ática, São Paulo.

Saramago, José (1990): O conto da ilha desconhecida, Companhia das Letras, São Paulo. Silveira, Nubia (2012): Julio Cortázar, um homem amável que gostava de escrever cartas. Disponível em <http:/ / www.sul21.com.br/jornal/2011/07> [26 novembro de 2012].

Todorov, Tzvetan (2004): Introdução à literatura fantástica (trad. Maria Clara Correa Castello), Perspectiva, São Paulo.

Walpole, Horace (1996): O Castelo de Otranto (trad. de Alberto Alexandre Martins), Nova Alexandria, São Paulo. 